Centre for Evidence Based Medicine, Nuffield Department of Primary Care Health Sciences, University of Oxford, Oxford

jeffrey.aronson@phc.ox.ac.uk Cite this as: BMJ 2022;376:039 http://dx.doi.org/10.1136/bmj.039 Published: 7 January 2022

\title{
When I use a word ... . Medical anniversaries in 2022
}

\section{Jeffrey K Aronson clinical pharmacologist}

Medical anniversaries in 2022 (for years ending in ' 22 and '72) include: publications of texts on etymology (by Isidore of Seville), dermatology (Girolamo Mercurialo), alchemy (the Turba Philosophorum), natural history (Francis Bacon), the plague (Daniel Defoe), and human and animal emotions (Charles Darwin); discoveries of nitrogen (by Henry Cavendish, Joseph Priestley, Daniel Rutherford, and Carl Scheele), the Bell-Magendie Law, the functions of gastric juices (William Beaumont), lysozyme (Alexander Fleming), vitamin D (Elmer McCollum and colleagues), and vitamin E (Herbert Evans and Katharine J Scott Bishop); the foundation of Guy's Hospital and of the American Public Health Association; acquisition of the Ebers Papyrus by Georg Ebers; treatment with insulin; the first use of the term "sickle cell anemia"; the introduction of Carapichea ipecacuanha into Europe from South America; and Nobel prizes for work on muscle metabolism (AV Hill and Otto Meyerhof in 1922) and the chemical structure of antibodies (Gerald Edelman and Rodney Porter in 1972).

\section{The Etymologiae of Isidore of Seville}

For the past six years I have been charting medical anniversaries year by year, ${ }^{1-6}$ restricting them to multiples of 50 years. The 2022 list includes anniversaries for years ending in ' 22 and ' 72 .

The earliest to note is the publication, in 622, of Etymologarium sive Originum, commonly known as the Etymologies, in 20 books, by Isidore of Seville. For those who are interested, I give the names of the 20 books at the end. ${ }^{7}$

Isidore was born in around 560 and became archbishop of Seville in around 6oo. He was canonised in 1598 and his saint's day is on 4 April.

In writing the Etymologiae, Isidore was something of an early wikipedist. He transmitted a vast amount of information gleaned from previous writers, many of them Roman, such as the polymath Marcus Terentius Varro (116-27 BCE), the lexicographer Verrius Flaccus (ca 55 BCE-20 CE), the philosopher Anicius Manlius Severinus Boethius (477-524), and the 3rd century jurist Julius Paulus. He also quotes many Latin poets, playwrights, and orators, including Virgil, Cicero, Terence, Ovid, Horace, Juvenal, and Martial. For the medical material in Books IV and XI he draws on sources such as the 2nd century Greek physician Soranus of Ephesus and Pliny the Elder's Naturalis Historia.

Isidore's etymologies are a mixed bunch. For example, he correctly traces "lethargy" back to the Greek word $\lambda \eta \theta \alpha \rho \gamma$ í $\alpha$, drowsiness, apoplexy to $\alpha \pi \sigma \pi \lambda \eta \xi$ '́s, a stroke, and sciatic to íxíov, the hip joint. However, he says that epilepsy is so called because "it hangs over the mind as much as it possesses the body," attributing it to the Greek

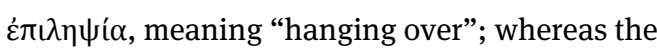
Greek word in fact comes from the verb $\varepsilon \pi i \lambda \alpha \mu \beta \alpha \alpha^{\prime} \nu \varepsilon เ v$, meaning to seize or take hold of. He claims that "tussis," a cough, comes from "the term for 'depth' in Greek, because it comes from deep in the chest, as opposed to higher in the throat, where the uvula tickles"; but it simply comes from the Latin word for a cough, tussis. And he says that a furuncle is so called because it is inflamed, from the Latin word fervere, to burn; but in fact it comes from the Latin furunculus, which literally means a little thief. The Romans called a knob on a vine a furunculus, presumably because they thought that it robbed the vine of its strength, and so a superficial tumour or a boil, which resembled it, was given the same name. Isidore then compounds the confusion by suggesting that "anthrax," which in Greek means charcoal, which burns, is a synonym for a furuncle, also because it is inflamed.

This last example reflects one of Isidore's several etymologistic methods, deriving meanings from similarities-a sort of folk etymology. ${ }^{8}$ For example, he suggests that "medicine" comes from the Latin word modus, one of whose several meanings is "moderation," since "medicine is applied not in full measure but little by little.” Leaning on humoral theory, he proposes that the Latin word for blood, sanguis, comes from suavis, sweet, because people who are of sanguine humour are sweet tempered and pleasant. And of "pestilence" he says that it is so called "as if it were pastulentia, because it consumes like fire," referring to the Latin word depascere, and to a passage from Book 5 of the Aeneid, in which Virgil describes the fire that entirely consumes a ship as "pestis" ("et toto descendit corpore pestis").

Some have suggested that this etymologising by similarity is an aspect of Isidore's pedagogical method, proposing that etymologies of this sort are not to be taken literally, but as kinds of mnemonics. Examples include the supposed origin of "rex," a king, from "recte," implying one who acts correctly, and "homo," a human being, from "humus," the ground from which Adam was supposedly fashioned. Sometimes a contrary meaning, which Isidore calls an antiphrasis, provides a memorable connection. For example, "lucus" in Latin, a grove, is so called, says Isidore, because therein there is no light "lux." But "lux" may be connected with the English word lea, a meadow, where light does shine.

Isidore's encyclopedia of word origins had a huge influence on medieval and later European culture. As a manuscript it was frequently copied and it was one of the earliest books to be printed, in 1472, another anniversary. Scholars made extensive use of it. Bede, for example, based his De Temporibus and its companion piece De Natura Rerum (both 703) on parts of it. And in the tenth canto of Il Paradiso, Dante 
mentions Isidore and Bede in the same breath. Isidore's influence even extends to our own day, since he invented the comma, colon, and period, adapting an earlier punctuation system of dots invented by Aristophanes, and other "nota sententiarum" (critical signs) that later developed into such symbols as question marks and quotation marks.

But much of Isidore's work is not etymology as we know it. That had to wait for 19th century advances in linguistics.

\section{Other medical anniversaries in $\mathbf{2 0 2 2}$}

1522: Birth, on 11 September, of Ulisse Aldrovandi (1522-1605), who founded the botanical garden in Bologna in 1568.

1572: Publication of De morbis cutaneis et omnibus corporis humani excremantis tractatus by Girolamo Mercurialo (1530-1606).

1572: Publication in Basel of the alchemical text, Auriferae artis quam chemiam vocant, antiquissimi authores, sive Turba philosophorum ("The most ancient authors, or the Assembly of Philosophers, on what they call alchemy"). The Turba Philosophorum was originally an Arabic text, thought to have been written in about $900 \mathrm{AD}$, reporting Greek alchemical theories in a discussion involving nine philosophers: Anaximander, Anaximenes, Anaxagoras, Empedocles, Archelaus, Leucippus, Ecphantus, Pythagoras, and Xenophanes, each of whom explains his theory. ${ }^{9}$

1622: Publication of Historia naturalis et experimentalis by Francis Bacon (1561-1626).

1672: Introduction of Carapichea ipecacuanha into Europe from South America.

1722: Thomas Guy obtains a lease on ground for the foundation of Guy's Hospital.

1772: Discovery of nitrogen ("phlogisticated air") independently by Henry Cavendish, Joseph Priestley, Daniel Rutherford (who published first), and Carl Scheele.

1772: Publication of A Journal of the Plague Year by Daniel Defoe; Defoe was only 5 years old at the time of the great plague of 1665 , and his account is thought to have been based on diaries of his uncle, Henry Foe, and other sources, such as Loimologia by Nathaniel Hodges. ${ }^{10}$

1822: Formulation of the Bell-Magendie Law, that nerve impulses from the spinal nerve roots are conducted in only one direction and that the anterior roots contain only motor fibres and the posterior roots only sensory fibres. ${ }^{11}$

1822: William Beaumont, the "Father of Gastric Physiology," studies the gastric juices of Alexis St Martin who, accidentally shot in the abdomen, had developed an external gastric fistula. ${ }^{12}$

1872: Publication of The Expression of the Emotions in Man and Animals by Charles Darwin.

1872: Foundation of the American Public Health Association.

1872: Acquisition, by the German Egyptologist Georg Moritz Ebers, of the papyrus, written in hieratic, that now bears his name, the Ebers Papyrus; it dates from the 16th century BCE and is one of the earliest medical treatises.

1922: Treatment with insulin of the first patient to be so treated for type 1 diabetes mellitus, Leonard Thompson, aged 14; he lived until 1935.

1922: Description, by Alexander Fleming, of lysozyme, also known as muramidase. ${ }^{13}$
1922: Discovery of vitamin D by Elmer McCollum and colleagues.

1922: Discovery by Herbert Evans and Katharine J Scott Bishop of a substance in lettuce and wheat germ, necessary for reproduction in experimental animals, later called vitamin $\mathrm{E}$.

1922: First use of the term "sickle cell anemia" by Verne Mason. ${ }^{14}$

1922: The Nobel Prize for Physiology or Medicine awarded to Archibald Vivian Hill (1886-1977) "for his discovery relating to the production of heat in the muscle," and to Otto Fritz Meyerhof (1884-1951) "for his discovery of the fixed relationship between the consumption of oxygen and the metabolism of lactic acid in the muscle.”

1972: The Nobel Prize for Physiology or Medicine awarded to Gerald Maurice Edelman (1929-2014) and Rodney R Porter (1917-85) "for their discoveries concerning the chemical structure of antibodies."

\section{Postscript}

The titles of the 20 books in Idisore's Etymologiae are: de grammatica; de rhetorica et dialectica; de quatuor disciplinis mathematicis; de medicina; de legibus et temporibus; de libris et officiis ecclesiasticis; de deo, angelis, sanctis et fidelium ordinibus; de ecclesia et sectis diversis; de linguis, gentibus, regnis, militia, civibus, affinitatibus; de vocabulis; de homine et portentis; de animalibus; de mundo et partibus; de terra et partibus; de aedificiis et agris; de lapidibus et metallis; de rebus rusticis; de bello et ludis; de navibus, aedificiis et vestibus; de penu et instrumentis domesticis et rusticis.

Competing interest: None declared.

Provenance and peer review: not commissioned, not peer reviewed.

Aronson J. Medical anniversaries in 2016. BMJ Opinion. 1 January 2016. https://blogs.bmj.com/bmi/2016/01/01/jeffrey-aronson-when-j-use-a-word-medical-anniversariesin-2016

2 Aronson J. Medical anniversaries in 2017. BMJ Opinion. 6 January 2017. https://blogs.bmj.com/bmj/2017/01/06/jeffrey-aronson-when-i-use-a-word-medical-anniversaries in-2017

3 Aronson J. Medical anniversaries in 2018. BMJ Opinion. 5 January 2018. https://blogs.bmi.com/bmi/2018/01/05/ieffrey-aronson-when-i-use-a-word-medical-anniversaries in-2018

4 Aronson J. Medical anniversaries in 2019. BMJ Opinion. 4 January 2019. https://blogs.bmj.com/bmi/2019/01/04/jeffrey-aronson-when-i-use-a-word-medical-anniversariesin-2019

5 Aronson J. Medical anniversaries in 2020. BMJ Opinion. 3 January 2020. https://blogs.bmj.com/bmi/2020/01/03/jeffrey-aronson-when-i-use-a-word-medical-anniversaries in-2020

6 Aronson J. Medical anniversaries in 2021. BMJ Opinion. 8 January 2021. https://blogs.bmj.com/bmi/2021/01/08/jeffrey-aronson-when-i-use-a-word-medical-anniversariesin-2021

7 Barney SA, Lewis WJ, Beach JA, Berghof O. The Etymologies of Isidore of Seville. Cambridge University Press, 2006doi: 10.1017/CB09780511482113.

8 Aronson J. Folk etymology. BMJ Opinion. 20 November 2020. https://blogs.bmj.com/bmi/2020/11/20/jeffrey-aronson-when-i-use-a-word-folk-etymology

9 Plessner M. The place of the Turba Philosophorum in the development of alchemy. Isis 1954;45:331-8. doi: 10.1086/348355 pmid: 13232807

10 Connor H. Defoe's Journal of the Plague Year: a study of risk management. J R Soc Med 2020;113:504-5. doi: 10.1177/0141076820962060 pmid: 33044126

11 Rengachary SS, Lee J, Guthikonda M. Medicosocial problems engendered with the discovery of the Bell-Magendie Law. Neurosurgery 2008;63:164-71, discussion 171-2. doi: 10.1227/01.NEU.0000335083.93093.06 pmid: 18728581

12 Ellis H. Alexis St. Martin, whose traumatic gastric fistula enabled William Beaumont to study the secretion of gastric juice in man. J Perioper Pract 2021;31:163-4 doi: 10.1177/1750458920957248 pmid: 33788660

13 Fleming A. On remarkable bacteriolytic element found in tissues and secretions. Proc R Soc Lond, B1922;xciii:306-17.

14 Mason VR. Sickle cell anemia. J Am Med Assoc 1922;79:1318-20doi: 10.1001/jama.1922.02640160038012 